\title{
POLA ASUH ORANG TUA DENGAN TEMPERAMEN REMAJA
}

\author{
Agisty Chintya Pelealu \\ Sefti Rompas \\ Yolanda Bataha
}

\author{
Program Studi Ilmu Keperawatan Fakultas Kedokteran \\ Universitas Sam Ratulangi \\ Email : agistyp@yahoo.com
}

\begin{abstract}
Temperament is a style of behaviour and a typical way of giving someone a response. One form of a negative temperament is fighting between groups of teenagers. Parenting is a way for families to shape children's behaviour in accordance with good norms and values and in accordance with community life. There are 4 types of parenting, which are: democratic, authoritian, permissive and neglectful. This study aims to find out ways of parenting with children's temperament. Research design that is using cross sectional study, as many as 105 research samples, respondents obtained using the total sampling method. The research instrument used was a questionnaire on parenting and temperament. Statistical test results using the chi square test, obtained $p=0,963$. This means that the value of $p=0,963>\alpha=0,05$. The conclusion of this study is that there is no relationship between parenting and temperament in adolescents in SMP Negeri 1 Sonder.
\end{abstract}

Keywords : Parenting, Temperament, Teenagers

Abstrak : Temperamen adalah gaya perilaku dan cara khas pemberian respon seseorang. Salah satu bentuk dari temperamen yang bersifat negatif yaitu perkelahian antar kelompok remaja Pola asuh merupakan cara keluarga membentuk perilaku anak sesuai dengan norma dan nilai yang baik dan sesuai dengan kehidupan masyarakat. Pola asuh ada 4 tipe, yaitu: demokratis, otoriter, permisif dan neglectful Penelitian ini bertujuan untuk mengetahui hubungan pola asuh orang tua dengan temperamentremaja. Desain penelitian yaitu menggunakan studi cross sectional, sampel penelitian sebanyak 105, responden didapat menggunakan metode total sampling. Instrumen penelitian yang digunakan berupa kuesioner pola asuh dan temperament. Hasil uji statistic menggunakan uji chi square, di dapatkan nilai $p=0,963$. Ini berarti bahwa nilai $p=0,963>\alpha=0,05$. Kesimpulan dari penelitian ini yaitu tidak terdapat hubungan antara pola asuh dan temperamen pada remaja di SMP Negeri 1 Sonder.

Kata kunci : Pola asuh, Temperament, Remaja

\section{PENDAHULUAN}

Temperamen adalah gaya perilaku dan cara khas pemberian respon seseorang (Santrock, 2009). Salah satu bentuk dari temperamen yang bersifat negatif yaitu perkelahian antar kelompok remaja. Pada umumnya yang melakukan perkelahian antar kelompok atau antar sekolah adalah remaja dari keluarga baik-baik, hanya karena pengabaian psikis tertentu dan mereka ingin mendapat perhatian lebih dari orang tua sendiri ataupun masyarakat. Perasaan senasib sepenanggungan anak- anak remaja yang merasa tidak mendapatkan kasih sayang dari orang tua dan masyarakat menjadikan anak remaja perlu memamerkan energi dan semangat hidupnya dalam bentuk perkelahian. Kegagalan sistem kontrol menjadikan remaja menyalurkannya melalui 3 kekerasan, agresi keras dan kejahatan yang dianggap mempunyai nilai-nilai yang lebih di mata remaja (Panjaitan Nurprenty, 2015). Penelitian yang dilakukan di Chichago 50-80\% temperamen ini terjadi seminggu sekali dan $20 \%$ terjadi hampir 
setiap hari dan 3 atau lebih temperamen terjadi selama kurang lebih 15 menit (Amelia Cevy, 2017). Penelitian lain di Northwestern Feinberg berdasarkan survei dari hampir 1.500 orang tua, studi ini menemukan bahwa 84\% dari anak-anak meluapkan frustasinya dengan mengamuk dalam satu bulan terakhir dan $8,6 \%$ diantaranya memiliki temperamen seharihari yang justru jika itu terjadi setiap hari merupakan tidak normal (Panjaitan Nurprenty, 2015). Sedangkan di Indonesia, biasanya mengalami ini dalam waktu satu tahun, 23 sampai 83\%. Beberapa penelitian menunjukkan bahwa temperamen terjadi sekurangnya sekali seminggu pada 50-80\% anak. Diperkirakan tiga perempat dari seluruh perilaku temperamen terjadi di rumah, namun temperamen terburuk sering ditujukan di tempat-tempat umum yang menjamin anak mendapat perhatian sebesarnya dengan membuat orang tua merasa malu (Hayes, Eileen. 2003).

Beberapa faktor penyebab temperamen adalah terhalangnya keinginan untuk mendapatkan sesuatu, ketidak mampuan remaja mengungkapkan diri, lelah, kurang tidur, pola asuh orangtua (Hasan, Maimunah 2011). Satu hal penting yang mempengaruhi temperamen adalah pola asuh orang tua. Cara orang tua yang mengasuh anaknya berperan menyebabkan temperamen misalnya, orang tua yang terlalu memanjakan anak sehingga anak mendapatkan apa keinginannya, bisa temperamen ketika permintaannya ditolak, orang tua yang terlalu mendominasi anak, orang tua yang mengasuh tidak konsisten, ayah dan ibu yang tidak sependapat (Hasan, Maimunah 2011).

Pola asuh merupakan cara keluarga membentuk perilaku anak sesuai dengan norma dan nilai yang baik dan sesuai dengan kehidupan masyarakat. Baumrind mengelompokkan pola asuh menjadi 4 tipe, yaitu: demokratis, otoriter, permisif dan Neglectful. (Fathi, 2010) mengatakan bahwa pola asuh demokratis lebih kondusif dalam mendidik anak. Orang tua yang demokratis lebih mendukung perkembangan anak terutama dalam hal kemandirian dan tanggung jawab. Orang tua yang otoriter cenderung merugikan karena anak tidak mandiri, kurang tanggung jawab, serta agresif, sedangkan orang tua yang permisif mengakibatkan anak kurang mampu menyesuaikan diri dengan lingkungan di luar rumah. Bentukbentuk pola asuh orang tua sangat erat hubungannya dengan kepribadian anak setelah menjadi dewasa. Dengan demikian, dapat disimpulkan bahwa pola asuh yang diterapkan oleh orang tua sangat dominan dalam membentuk kepribadian anak sejak dari kecil sampai anak menjadi dewasa (Subhan Syam, 2013).

Penelitian oleh (Kirana Rizkia, 2013) tentang temperamen dan kecemasan pada masa remaja yang bertujuan untukmendapatkan gambaran awal mengenai perilaku tantrum. Hasil penelitiannya menunjukkan bahwa dari 33 orangresponden terdapat 26 orang $(79 \%)$ melaporkan frekuensi temperamen remaja dalam kategori sering terjadi, dengan rincian 12 responden melaporkan temperamen terjadi harian, dan 14 responden melaporkan temperamen terjadi mingguan. Tujuh orang sisanya melaporkan frekuensi temperamen sangat kurang, dari yang terjadi kurang sekali sebulan sampai yang tidak pernah.

Hasil penelitian tersebut juga menemukan bahwa 10 responden melaporkan intensitas perilaku temperamen anaknya dalam kategori berat, 16 responden dengan kategori sedang dan 6 responden dalam kategori ringan. (Dinantia Fadila, 2014) tentang komposisi perilaku temperamen pada remaja. Penelitian ini bertujuan untuk mengidentifikasi kemarahan dan distress utama yang independen dengan emosi serta unsur utama dari temperamen. Hasil penelitiannya menunjukkan bahwa prevalensi temperamen meningkat dari $87 \%$ pada usia 18-24 bulan menjadi $91 \%$ pada usia 30-36 bulan dan kemudian menurun menjadi $59 \%$ pada usia 42- 48 bulan. 
Penelitian oleh Rohner dkk (2007) yang bertujuan untuk mengetahui pengaruh pola asuh penerimaan dan penolakan yang diterapkan orang tua terhadap remaja. Hasil penelitiannya menunjukkan bahwa pengalaman masa kecil seseorang sangat mempengaruhi perkembangan karakter dan kecerdasan emosionalnya. Penelitian yang menggunakan teori Parental Acceptance Rejection tersebut menunjukkan bahwa pola asuh orang tua, baik yang menerima maupun yang menolak anaknya akan mempengaruhi perkembangan emosi, perilaku, sosial kognitif, serta fungsi psikologisnya.

Berdasarkan studi pendahuluan yang dilaksanakan pada tanggal 25 Juli 2018 di SMP Negeri 1 Sonder pada kelas VIII karena merupakan usia remaja awal yaituumur 13-14 tahun dengan melakukan wawancara kepada kepala sekolah terdapat 50 siswa laki-laki dan 55 siswa perempuan di kelas VIII SMP Negeri 1 Sonder dan di dapati belum pernah ada penelitian seperti ini di SMP Negeri 1 Sonder dan terdapat 10 siswa dan 5 diantaranya cenderung kurang mampu menyesuaikan diri dengan lingkungan diluar rumah dan 5 diantaranya sering bertindak kasar dan agresif. Untuk memperkuat pernyataan tersebut dilakukan pembagian kuesioner kepada siswa kelas VIII sebagai survey awal sebelum penelitian. Dari survey awal yang dilakukan pada 10 siswa terdapat 7 siswa yang memiliki pola asuh kurang baik dari orang tua dan 3 siswa memiliki pola asuh baik dari orang tua. Berdasarkan gambaran data di atas peneliti tertarik untuk melakukan penelitian dengan judul 'Hubungan pola asuh orang tua dengan temperamen remaja.

\section{METODE PENELITIAN}

Penelitian ini menggunakan metode dengan pendekatan cross sectional. Cross sectional adalah penelitiana yang mendesain pengumpulan datanya dilakukan pada saat titik waktu, fenomena yang diteliti adalah selama satu periode pengumpulan data, pada dasarnya variabel dependen dan variabel independent dikumpulkan dan diukur pada waktu yang bersamaan(Swarjana, 2012). Penelitian ini dilakukan di SMP Negeri 1 Sonder. Sekolah menengah pertama ini adalah salah satu sekolah yang terletak di jaga 3 tounelet 1 kecamatan sonder. Penelitian ini dilakukan pada tanggal 11 maret 2019 pada jam 11 siang. Penelitian ini menggunakan total sampling dengan jumlah siswa/siswi kelas VIII berjumlah 105 orang.

Kuesioner ini sebelumnya telah digunakan oleh Moh.Abdus Sofa. Uji yang digunakan adalah uji statistik chi-square dengan hasil $\mathrm{p}=0,963$ dimana lebih besar dari nilai $\alpha=0,05$ sehingga disimpulkan tidak ada hubungan pola asuh dengan temperamen remaja di SMP Negeri 1 Sonder. Pengumpulan data menggunakan kuesioner dengan pertanyaaan-pertanyaan terkait dengan tujuan penelitian. Yang dimaksud dengan instrument penelitian adalah alat-alat yang dipakai dalam pengumpulan data, instrument ini dapat berupa kuesioner formulir-formulir lain yang berkaitan dengan pendataan.

Alat ukur yang digunakan adalah kuesioner pola asuh yang terdiri dari 37 pernyataan masing - masing terdiri dari 4 jawaban sangat setuju, setuju, tidak setuju, dan sangat tidak setuju. Jika jawaban sangat setuju diberi nilai 1 , jawaban setuju diberi nilai 2, jika jawaban tidak setuju diberi nilai 3 dan jika jawaban sangat tidaksetuju diberi nilai 4. Pada pernyataan temperamen jumlah 24 masing-masing terdiri dari 4 jawaban sangat setuju, setuju, tidak setuju, sangat tidak setuju. Jika jawaban sangat setuju diberi nilai 1 , jika jawaban setuju diberi nilai 2, jika jawaban 
tidak setuju diberi nilai 3 dan jikajawaban sangat tidak setuju diberi nilai 4. SMP Negeri 1 Sonder yang merupakan wilayah penelitian untuk melakukan penelitian ini. Untuk memperoleh data tentang pola asuh orang tua dengan temperamen yang ada SMP Negeri 1 Sonder maka peneliti mendatangi SMP tersebut kemudian peneliti menjelaskan maksud dan tujuan datang kesana serta menunjukkan surat persetujuan untuk melakukan penelitian. Setelah memperoleh data dari SMP Negeri 1 Sonder, maka pada tanggal 11 maret 2019 peneliti mulai melakukan penelitan dengan cara mengumpulkan siswa yang akanmenjadi responden dalam penelitian ini berdasarkan data dari SMP Negeri 1 Sonder.

Prosedur pengambilan data yang dilakukan adalah sebagai berikut: Editing: Untuk memeriksa data apa sudah sesuai dengan harapan serta memerika kelengkapan dan keseragaman data. Coding: untuk mempermudah pada saat analisis data dan juga mempercepat pada saat entry data. Processing: Dilakukan setelah seluruh variabel diberi kode. Data yang telah diberi kode kemudian dimasukkan terlebih dahulu dalam master table. Cleaning: Proses ini meyakinkan bahwa data yang telah dimasukkan betul-betul bersih dari kesalahan (Setiadi, 2013)

\section{HASIL dan PEMBAHASAN}

\section{Karakteristik Responden}

Tabel 1. Distribusi Jenis Kelamin Responden

\begin{tabular}{ccc}
\hline Jenis Kelamin & n & \% \\
\hline Laki-laki & 49 & 47,0 \\
Perempuan & 56 & 53,3 \\
\hline Total & $\mathbf{1 0 5}$ & $\mathbf{1 0 0}$ \\
\hline
\end{tabular}

Tabel 1 diatas menunjukan bahwa dari 105 responden yang diteliti mayoritas data jenis kelamin responden yaitu perempuan dengan jumlah 56 siswa dan sisanya berjenis kelamin laki-laki berjumlah 49 siswa.
Tabel 2. Distribusi responden berdasarkan umur siswa/siswi SMP Negeri 1 Sonder

\begin{tabular}{ccc}
\hline Umur & n & \% \\
\hline 12 tahun & 25 & 24,0 \\
13 tahun & 71 & 67,6 \\
14 tahun & 9 & 8,4 \\
\hline Total & $\mathbf{1 0 5}$ & $\mathbf{1 0 0}$ \\
\hline
\end{tabular}

Tabel 2 menunjukan bahwa umur responden paling banyak yakni umur 13 tahun yang berjumlah 71 responden sedangkan umur responden paling sedikit yakni 14 tahun yang berjumlah 9 responden.

\section{Analisis Univariat}

Tabel 3. Distribusi frekuensi responden berdasarkan pola asuh orang tua di SMP Negeri 1 Sonder

\begin{tabular}{ccc}
\hline Pola Asuh & n & \% \\
\hline Otoriter & 33 & 31,4 \\
Permisif & 28 & 26,7 \\
Demokratis & 24 & 22,9 \\
Neglectful & 20 & 19,0 \\
\hline Total & $\mathbf{1 0 5}$ & $\mathbf{1 0 0}$ \\
\hline
\end{tabular}

Tabel 3 menunjukan bahwa distribusi frekuensi responden paling banyak yakni pola asuh otoriter yang berjumlah 33 sedangkan yang paling sedikit yakni pola asuh neglectful yang berjumlah 20 .

Tabel 4. Distribusi frekuensi reponden berdasarkan temperamen pada remaja di SMP Negeri 1 Sonder

\begin{tabular}{ccc}
\hline $\begin{array}{c}\text { Temperamen } \\
\text { Remaja }\end{array}$ & n & \% \\
\hline Sulit & 0 & 0 \\
Sedang & 76 & 72,4 \\
Mudah & 29 & 27,6 \\
\hline Total & $\mathbf{1 0 5}$ & $\mathbf{1 0 0}$ \\
\hline
\end{tabular}

Tabel 4 menunjukan bahwa mekanisme koping responden paling banyak yakni temperamen sedang yang berjumlah 76 sedangkan yang paling sedikit yakni temperamen sulit yang berjumlah 0 . 


\section{Analisis Bivariat}

Tabel 5. Hasil analisis Hubungan Pola Asuh Orang Tua dengan Temperamen Remaja di SMP Negeri 1 Sonder

\begin{tabular}{lcccccccccc}
\hline & \multicolumn{8}{c}{ Temperamen } & \multirow{2}{*}{$P$} \\
\cline { 2 - 7 } Pola Asuh & \multicolumn{1}{c}{ Sulit } & \multicolumn{3}{c}{ Sedang } & \multicolumn{2}{c}{ Mudah } & \multicolumn{2}{c}{ Total } & \\
\cline { 2 - 8 } & $\mathrm{n}$ & $\%$ & $\mathrm{n}$ & $\%$ & $\mathrm{n}$ & $\%$ & $\mathrm{n}$ & $\%$ & \\
\hline Otoriter & 0 & 0 & 25 & 23,9 & 8 & 9,1 & 33 & 33,0 & \\
Permisif & 0 & 0 & 20 & 20,3 & 8 & 7,7 & 28 & 28,0 & \multirow{2}{*}{0,963} \\
Demokratis & 0 & 0 & 17 & 17,4 & 7 & 6,6 & 24 & 24,0 & \\
Neglectful & 0 & 0 & 14 & 14,5 & 6 & 5,5 & 20 & 20,0 & \\
\hline Jumlah & 0 & 0 & 76 & 76,1 & 29 & 28,9 & 105 & 100 & \\
\hline
\end{tabular}

Berdasarkan hasil penelitian menunjukkan nilai $\mathrm{p}=0,963$ di mana lebih besar dari nilai $\alpha=0,05$, sehingga di simpulkan tidak ada hubungan pola asuh dan temperamen. Penelitian ini menunjukkan 33 pola asuh orang tua otoriter (Otoritarian), 28 pola asuh orangtua permessive, 24 pola asuh orang tua demokratis (Otoritatif), dan 20 neglectful dan temperament remaja the difficult child (sulit) 0, the slow-to-warm-up child (sedang) 72, dan the easy child (mudah) 27.

\section{Pembahasan}

\section{Pola Asuh}

Hasil penelitian menunjukkan bahwa pola asuh demokrasi merupakan pola asuh yang diterapkan oleh orang tua kepada anaknya karena pola asuh demokrasi memiliki ciri-ciri yaitu memberi kesempatan kepada anakanaknya untuk mandiri dan mengembangkan kontrol internalnya, diakui keberadaannya dan dilibatkan dalam pengambilan keputusan di dalam keluarga, bimbingan dan komunikasi dua arah. Hasil penelitian menunjukkan terdapat $33(33 \%)$ orang tua yang masih menerapkan pola asuh otoriter. Orang tua dengan pola asuh otoriter dinilai rendah dalam penggunaan kontrol rasional. Mereka mengandalkan penegasan, kekuasaan, disiplin, keras, kurang hangat, kurang mengasuh, kurang mengasihi, kurang simpatik pada anakanaknya, tidak mendorong anak remaja mereka untuk mengemukakan ketidaksetujuan atas keputusan atau peraturan orang tua dan memberikan sedikit kehangatan (Hurlock, 2006). Berbeda dengan orang tua yang menerapkan pola asuh permisif. Hasil penelitian menunjukkan sebanyak 28 orang (28\%) masih menerapkan pola asuh permisif yaitu orang tua yang serba memperbolehkan anak-anaknya berbuat apa saja. Hasil penelitian menunjukan bahwa pola asuh neglectful $20(20 \%)$ orang yang meneraokan pola asuh neglectful. Pola asuh neglectful merupakan orang tua yang mengkombinasikan rendahnya demandingness/ control dan acceptancel responsive yang rendah pula. Secara relatif tidak melibatkan diri pada pengasuhan anak dan tidak terlalu peduli pada anak-anak.

\section{Temperamen}

Hasil penelitian tentang temperamen yang dapat dilihat pada tabel 4 menunjukkan bahwa dari 105 orang sebanyak 29 orang $(27,6 \%)$ memiliki temperamen mudah $0(0 \%)$ memiliki temperamen sulit dan 76 orang $(72,4 \%)$ memiliki temperamen sedang. Berdasarkan hasil penelitian dapat dilihat bahwa mayoritas anak memiliki temperamen sedang. Hal ini menunjukkan bahwa temperamen anak yang temperamen sulit memiliki ciri sangat aktif, peka rangsang dan mempunyai kebiasaan yang tidak teratur (Wong, 2008). Hasil penelitian yang diperoleh yaitu masih ada anak yang tidak mudah gembira dengan pujian, menyesuaikan diri dalam sehari atau dua hari terhadap perubahan rutinitas dan tidaklsenang atau tersenyum dalam keadaan lelah. Pada tabel 4 dapat dilihat bahwa terdapat $29(27,6 \%)$ anak memiliki temperamen mudah. Hal ini menunjukkan bahwa temperamen mudah adalah anak yang santai, bertemperamen mudah, memiliki kebiasaan yang teratur dan dapat diprediksi, dan memiliki pendekatan yang positif terhadap stimulus baru. Mereka terbuka dan 
dapat beradaptasi terhadap perubahan dan menunjukkan intensitas mood yang ringan sampai sedang yang biasanya bersifat positif (Wong, 2008).Pada tabel 4 dapat dilihat bahwa terdapat $76(72,4 \%)$ anak yang memiliki temperamen sedang. Anak dalam kategori ini biasanya bereaksi secara negatif dan dengan intensitas ringan terhadap stimulus baru, kecuali jika ditekan, lambat beradaptasi terhadap kontak berulang. Mereka hanya berespon dengan penolakan ringan namun pasif terhadap sesuatu yang baru atau asing atau perubahan rutinitas (Wong, 2008).

\section{Hubungan Pola Asuh Orang Tua Dengan Temperamen Remaja}

Berdasarkan hasil penelitian menunjukkan 33 pola asuh orang tua otoriter (Otoritarian), 28 pola asuh orang tua permessive, 24 pola asuh orang tua demokratis (Otoritatif), dan 20 neglectful dan temperament remaja the difficult child (sulit) 0, the slow-to-warm-up child (sedang) 72, dan the easy child (mudah) 27. Hasil ini tidak ada hubungan. Berdasarkan data diatas dapat diketahui bahwa pola asuh otoriter tidak menghasilkan temperamen anak sulit. Hal ini tidak sejalan dengan pendapat (Panjaitan Nurprenty, 2015) yang menjelaskan pola asuh otoriter dapat berdampak buruk pada anak, yaitu anak merasa tidak bahagia, ketakutan, tidak terlatih untuk berinisiatif, selalu tegang, cendrung ragu, tidak mampu menyelesaikan masalah, kemampuan komunikasinya buruk serta gugup, akibat seringnya mendapat hukuman dari orang tua. Orang tua memaksa anak untuk patuh pada nilai-nilai mereka, serta mencoba membentuk tingkah lakunya serta cendrung mengekang keinginan anak. Orang tua tidak mendorong serta memberi kesempatan kepada anak untuk mandiri dan jarang memberi pujian (Panjaitan Nurprenty 2015).

\section{SIMPULAN}

Berdasarkan hasil penelitian kepada siswasiswi SMP Negeri 1 Sonder, maka dapat ditarik kesimpulan yaitu pola asuh yang digunakan orangtua pada siswa-siswi SMP Negeri 1 Sonder lebih banyak pola asuh otoriter. Temperamen remaja pada siswasiswi SMP Negeri 1 Sonder lebih banyak nilai sedang dan Tidak terdapat hubungan antara pola asuh orangtua dengan temperamen remaja pada siswa-siswi SMP Negeri 1 Sonder.

\section{DAFTAR PUSTAKA}

Amelia Cevy (2017), Hubungan Pola Asuh Orang Tua Dengan Temper Tantrum Pada Anak Usia 3-5 Tahun. [skripsi] Batam, Universitas Batam. (Skripsi hal 15)

Dinantia Fadila (2014). Hubungan Pola Asuh Orang Tua Dengan Frekuensi dan Intensitas Perilaku Temper Tantrum Pada Anaka Toddler, [skripsi]. Riau, Universitas Riau. (Skripsi hal 20)

Fathi. (2010). Mendidik anak dengan AlQur'an. Bandung: Oasis (Book hal 2)

Hasan, Maimunah. (2011). Pendidikan Anak Usia Dini. Yogyakarta: Diva Press. (Book hal 5)

Hayes, Eileen. (2003). Tantrum. Jakarta: Erlangga. (Book hal 10)

Hurlock, E.B. (2006). Psikologi perkembangan: suatu pendekatan sepanjang rentang kehidupan (5 ed.). Jakarta: Erlangga. (Book hal 25)

Kirana Rizkia, (2013). Hubungan Pola Asuh Orang Tua Dengan Temper Tantrum Pada Anak Pra Sekolah. (Skripsi hal 22) 
Panjaitan, Nurprenty (2015). Hubungan tipe pola asuh orang tua dengan temperamen pada remaja. [skripsi]. Medan: Universitas Sari Mutiara. (Skripsi hal 30)

Rohner, R. P., Khaleque, A., \& Cournoyer, D. E. (2007). Parental acceptance rejectiontheory. Diperoleh tanggal 5 November 2013. (Book hal 10)

Santrock, John W (2009). Adolescence (6 ed.). Jakarta: Erlangga. (Book hal 15)

Setiadi. 2013. Konsep dan Praktek Penulisan Riset Keperawatan. Ed 2. Yogyakarta. Graha Ilmu. (Book hal 40)

Subhan Syam (2013). Hubungan Pola Asuh Orang Tua Terhadap Kejadian Temper Tantrum Anaka Usia Toddler Di Paud Dewi Kunti Surabaya [skripsi]. Surabaya, Universitas Airlangga. (Book hal 25)

Swarjana, Ketut. (2012) Metodologi Penelitian Kesehatan. Yogyakarta: ANDI. (Book hal 37)

Wong, Donna L (2008). Buku Ajar Keperawatan Pediatrik. Edisi 6. Jakarta: EGC. (Book hal 5) 